\title{
SHEAR PROPERTIES OF PLYWOOD-SHEATHED WALL PANELS WITH OPENING*
}

\author{
by MOTOI YASUMURA* and HIDEO SUGIYAMA** \\ Members of A. I. J.
}

\section{INTRODUCTION}

In Japan the shear strength of a wooden building against horizontal forces has in principle estimated on the basis of the assumption that two thirds of the horizontal load applied to the building is supported by linear bearing walls without opening and the rest (one third) supported by no-bearing members, that is, wall parts right above and/or below opening, narrow wall parts adjacent to an opening, walls perpendicular to the direction of horizontal force, etc.

This simple design procedure sometimes causes under- or over-estimation of shear strength of a wooden building, so it is necessary to estimate precisely the effect of no-bearing members on the shear strength of a wooden building.

The aim of the study presented here was to provide the information for the estimation of racking strength of a wall panel with opening and to investigate the influence of the shape and area of opening and of the method of application of plywood-sheathing on shear properties of wall panels.

In this study, tests were made on the reduced-scale wall panels on the basis of standard specification of North American wooden frame construction, and displacements of studs and plywood-sheathings were precisely measured.

Although test results presented here indicate almost the same tendencies as those on full-scale test ${ }^{(1)(2)(3)(4)}$, further study would be necessary to apply to full-size wall panels.

\section{EXPERIMENT}

\section{1 DESCRIPTION OF WALL PANEL SPECIMENS}

All members consisting of each wall panel were reduced to one-third of the standard dimension in North American wooden frame consturction (See Fig. 1).

Frame members were of air-dried western hemlock and were 13-by $30 \mathrm{~mm}$, except for 26 -by $30 \mathrm{~mm}$ members
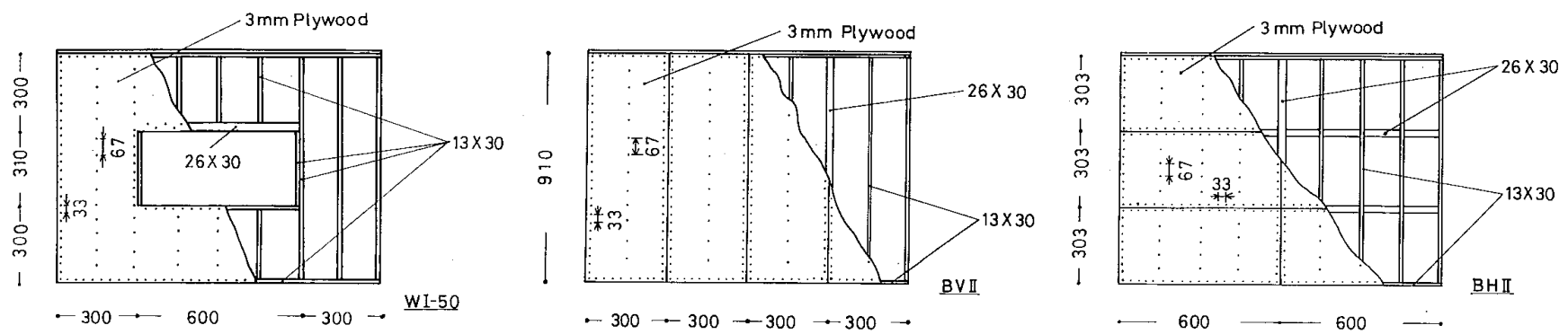

Fig. 1 Examples of wall panel specimens

+ This report is based upon a thesis for a Ph. D. degree of the first author (6). The content of this paper was briefly and separately presented at the Annual Meetings of Architectural Institute of Japan (1976 and 1979) (5) (7), and at the 27 th Annual Meeting of the Japan Wood Research Society (1977).

* Research officer, Building Research Institute, Ministry of Construction. Dr. Agr. Former Assistant Professor, Dept. of Forest Products, The University of Tokyo.

** Professor, Dept. of Forest Products, The University of Tokyo, Dr. Eng. 
arranged along the vertical joints of plywood-sheathings. Studs, spaced $15 \mathrm{~cm}$ on center, were connected both to bottom plate and to double top plates with end nailing of N32 wire nails ( $32 \mathrm{~mm}$ in length and 1.85 $\mathrm{mm}$ in diameter), .

Three millimeter thick lauan plywood (three plies glued with urea resin) was applied to one side of the frame of a wall panel with N19 wire nails $(19 \mathrm{~mm}$ in length and $1.5 \mathrm{~mm}$ in diameter) which were spaced 3.3 $\mathrm{cm}$ apart around the perimeters of a plywood sheet and $6.7 \mathrm{~cm}$ along the intermediate supports (See Fig. 1).

Specimens were divided into two

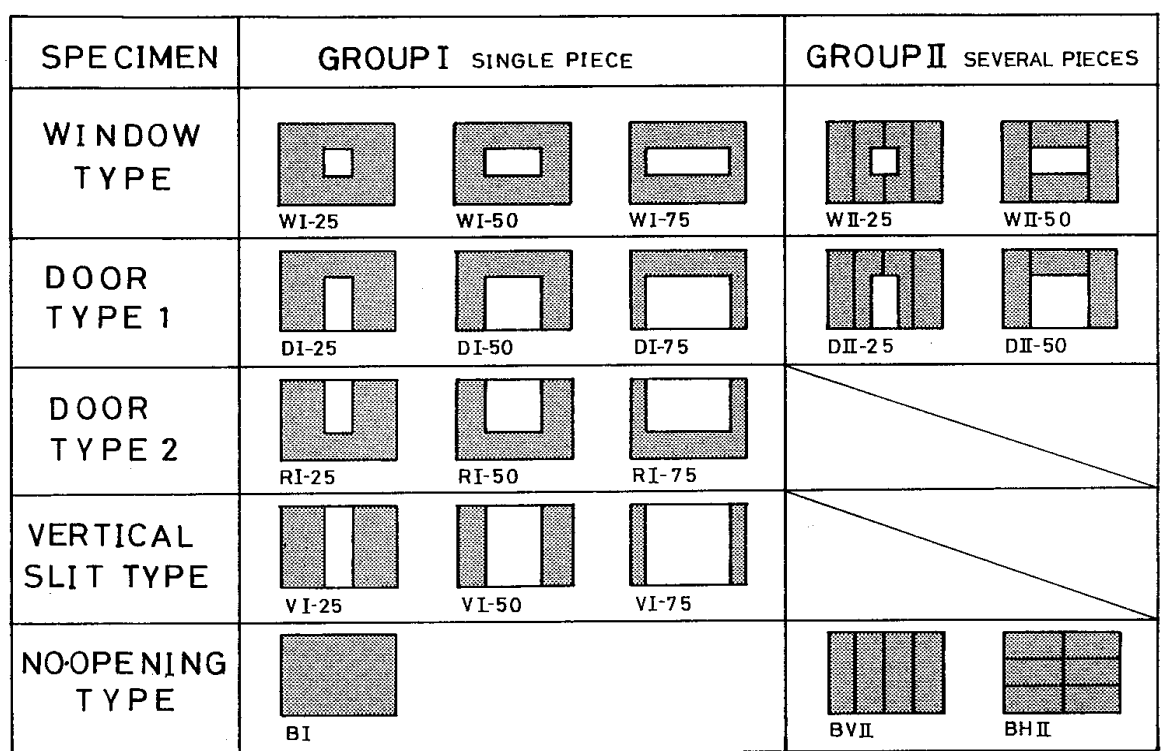

Fig. 2 Groups and types of wall panel specimens (25, 50 and 75 show opening length ratio) groups, according to the application method of plywood-sheathings;

Group I : One face of a wall panel was sheathed with a single piece of 91 -by $120 \mathrm{~cm}$ plywood.

Group II : One face of a wall panel was sheathed with several pieces of 30-by $90 \mathrm{~cm}$ or 30 -by $60 \mathrm{~cm}$ plywood.

Each group was subdivided into several types in respect to the shape and area of an opening as shown in Fig. 2. As seen in Fig. 2 , the specimen names end with numbers 25,50 and 75 ; these numbers show the opening length ratio expressed as a percentage of opening length to wall length.

\subsection{TEST METHODS}

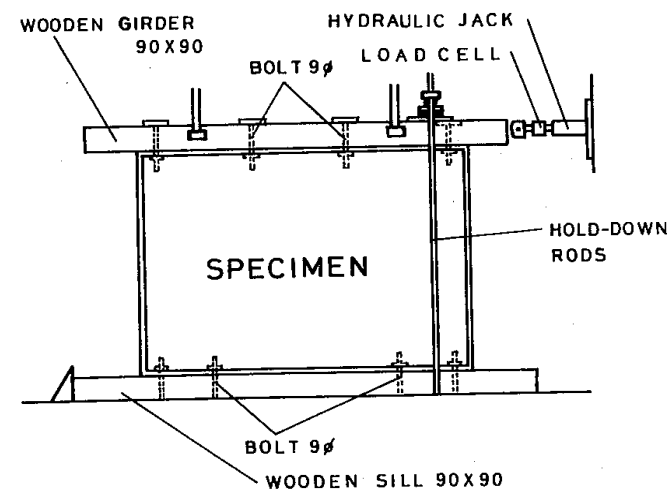

Fig. 3 Test setup for racking test

Fig. 3 shows the test setup for racking test of a wall panel. Double top plates were bolted to a 9 -by $9 \mathrm{~cm}$ wooden girder with four $9 \mathrm{~mm}$ bolts, and bottom plate was bolted to a 9 -by $9 \mathrm{~cm}$ wooden sill which was anchored to a steel member with four $9 \mathrm{~mm}$ bolts. The horizontal force was applied at the end of wooden girder.

The loading schedule for each panel type was as follows;

(1) In Group I, one specimen was at first loaded until failure under one way loading, and then two others under reversed cyclic loading (three or four cycles).

(2) In Group II , two specimens were loaded until failure under one way loading.

\section{RESULTS AND DISCUSSION}

\subsection{FAILURE PATTERNS}

In the window type of Group I, plywood buckled at the corners of an opening, and afterwords suddenly failed due to tension failure at the other corners of an opening (See Fig. 4 (a)). Similar failure patterns were observed in the door type of Group I.

In the no-opening and vertical slit types of Group I and in all Group II specimens, the nails fastening plywood to frame members were deformed remarkably due to shearing force and eventually punched out plywood (See Fig. 4 (b)).

In Group II specimens with a comparatively large opening (W II -50 and D II -50), not only the nails yieled, but also plywood buckled at the corners of an opening.

3.2 SHEAR DEFORMATION OF WALL PANEL

3.2.1 EXPERIMENTAL RESULTS 


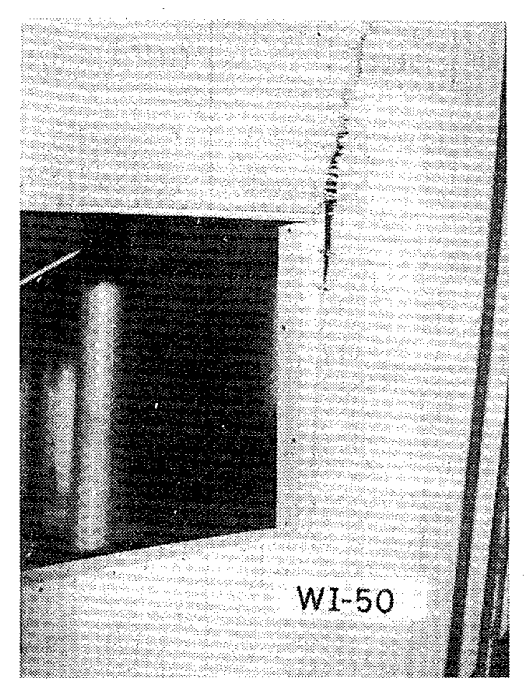

Fig. 4 (a) Tension failure of plywood at the corner of a window (Group : WI-50)

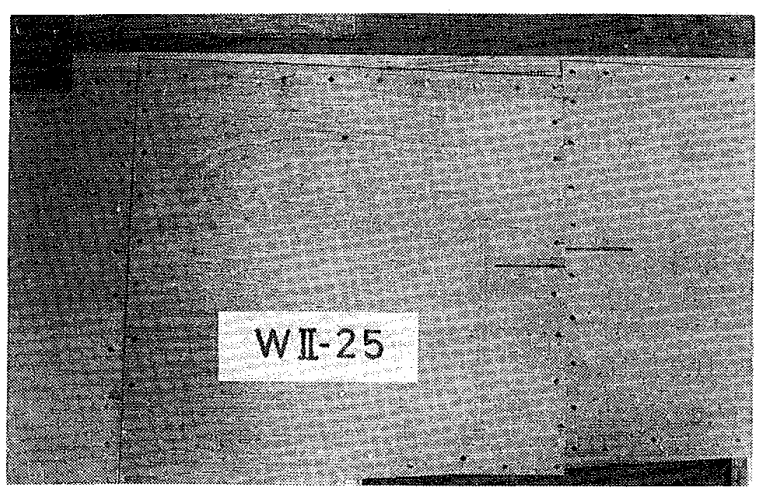

Fig. 4 (b) Rotation of plywood-sheathings due to yield of nail joints (Groud II : W II -25)

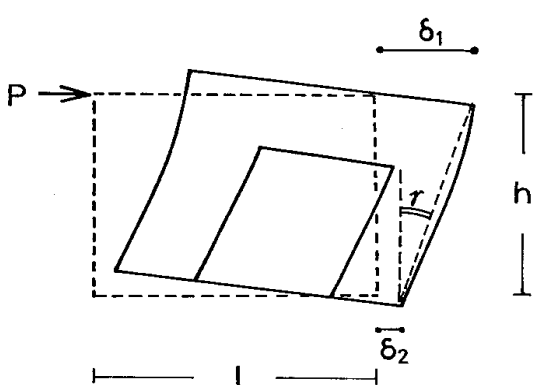

APPARENT SHEAR STRAIN

$$
r=\frac{\delta_{1}-\delta_{2}}{h}
$$

Fig. 5 Definition of apparent shear strain

Figs. 6 and 7 show the deformation of wall panels of Group I and II specimens. Apparent shear strain is defined as shown in Fig. 5.

Figs. 8 and 9 show the horizontal displacement ratio (ratio of horizontal displacement at the measured points to that at the top of wall panel) in Group I and II specimens. Figs. 10 and 11 show the vertical displacements of studs and of plywood sheets.

\subsubsection{DEFORMATION IN GROUP I SPECI-}

\section{MENS}

The following tendencies can be found from Figs. 6, 8 and 10 ;

(1) In the vertical slit type, two side walls deform and rotate almost equally and the horizontal displacement of each wall at the mid-height is approx-
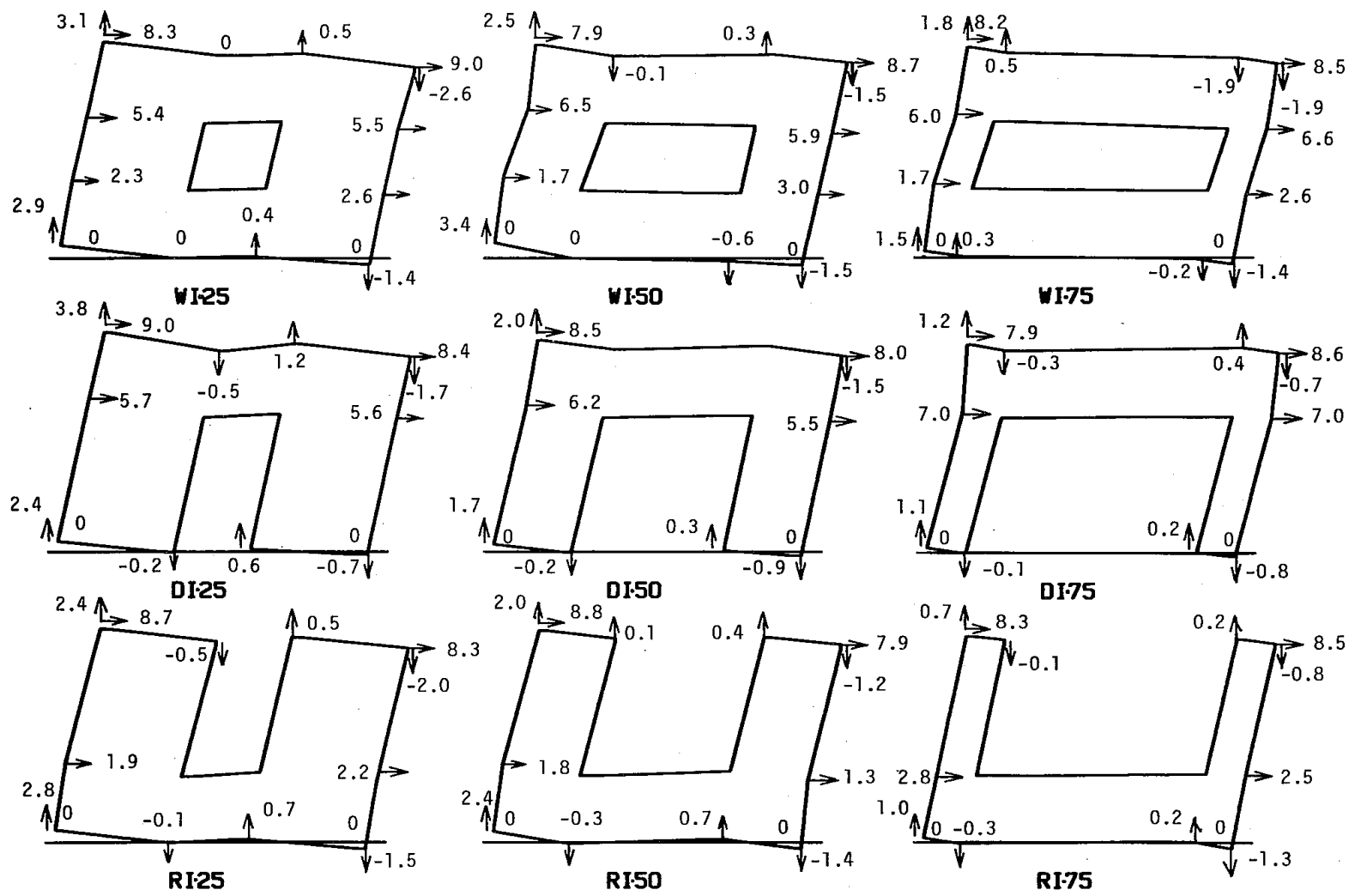

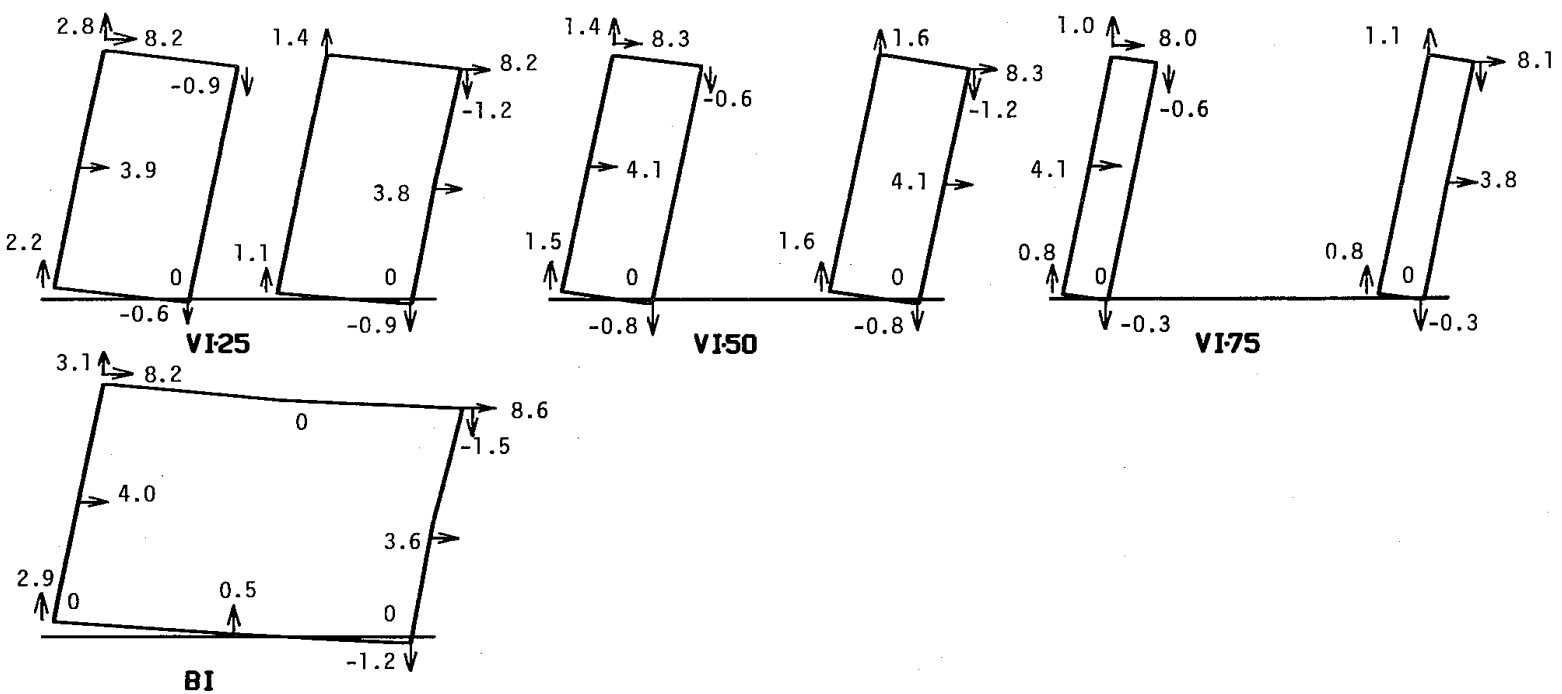

Fig. 6 Deformation of Group I specimens at apparent shear strain of 1/100 rad. (unit : mm)
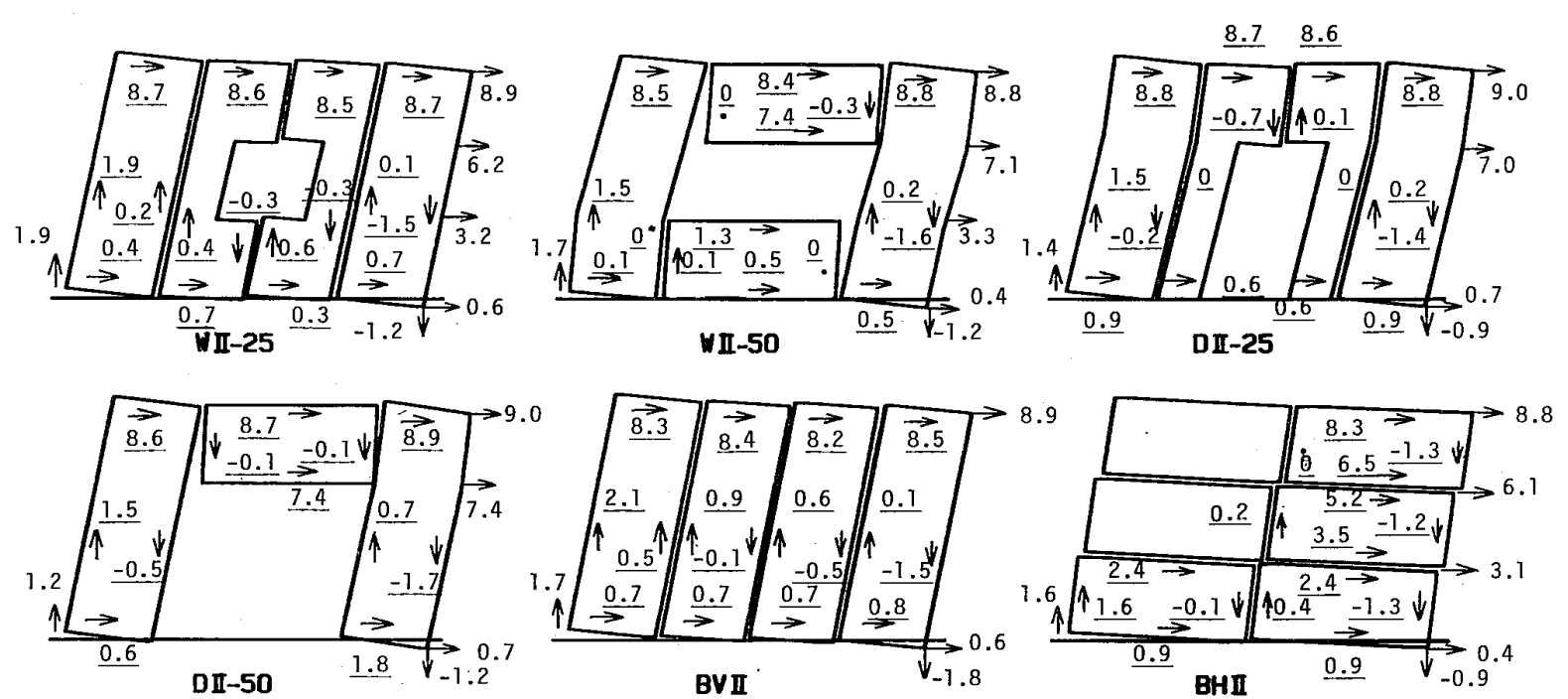

Fig. 7 Deformation of Group II specimens at apparent shear strain of $1 / 100 \mathrm{rad}$. Underlined numbers show displacement of ply wood sheet. (unit : mm)

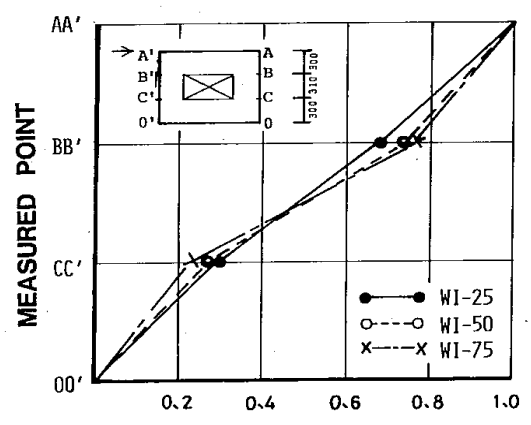

HORIŻONTAL DISPLACEMENT RATIO

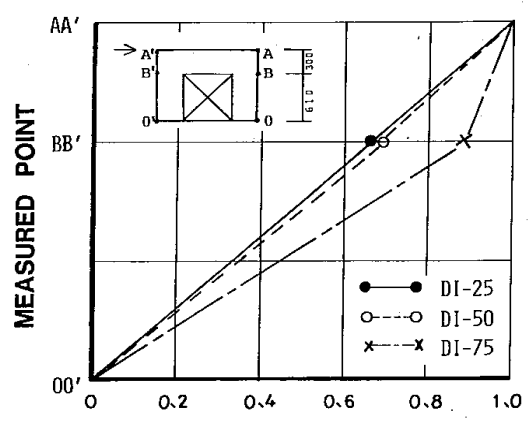

HORIZONTAL DISPLACEMENT RATIO

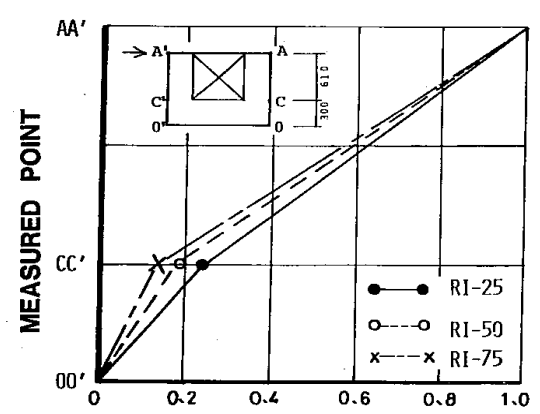

HORIZONTAL DISPLACEMENT RATIO

Fig. 8 Horizontal displacement of studs in Group I specimens (Ratio of horizontal displacement at the measured points to that at the top of wall panel) 


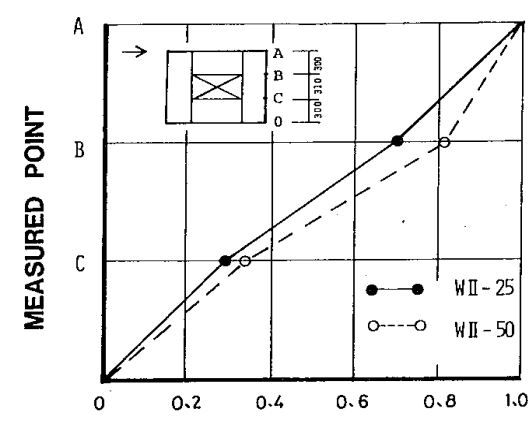

HORIZONTAL DISPLACEMENT RATIO

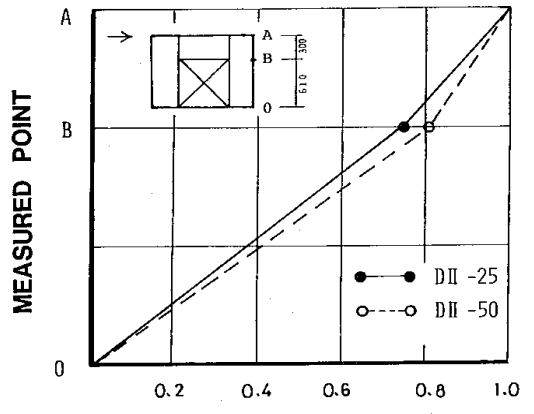

HORIZONTAL DISPLACEMENT RATIO

Fig. 9 Horizontal displacement of studs in Group II specimens (Ratio of horizontal displacement at the measured points to that at the top of wall panel)
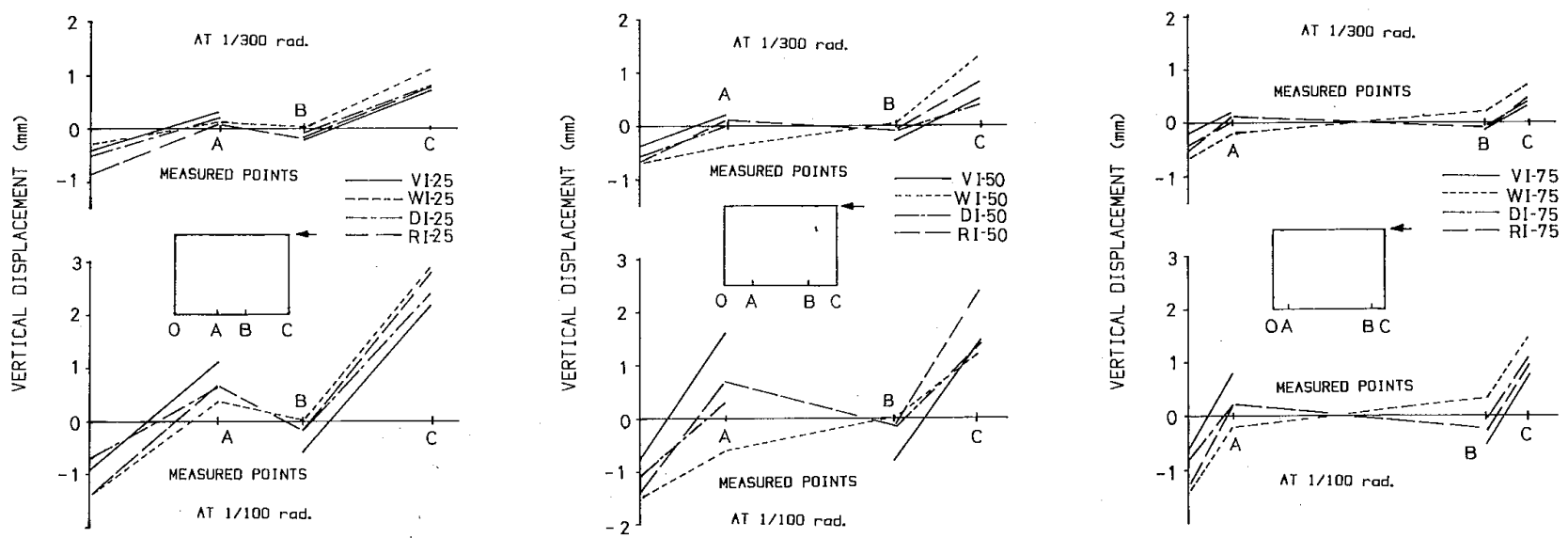

Fig. 10 Vertical displacement of studs in Group I specimens
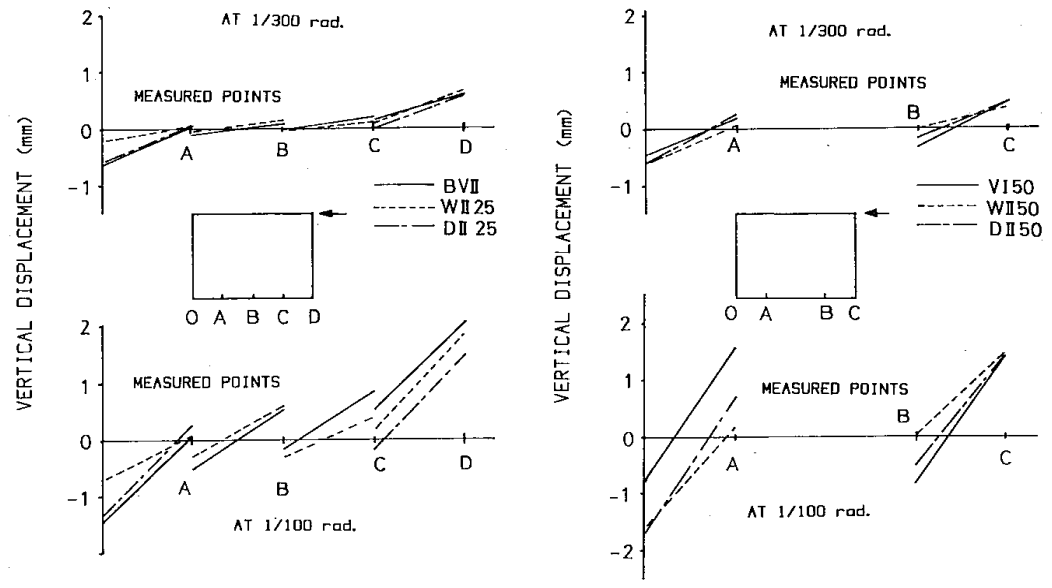

Fig. 11 Vertical displacement of the bottom of plywood sheets in Group II specimens

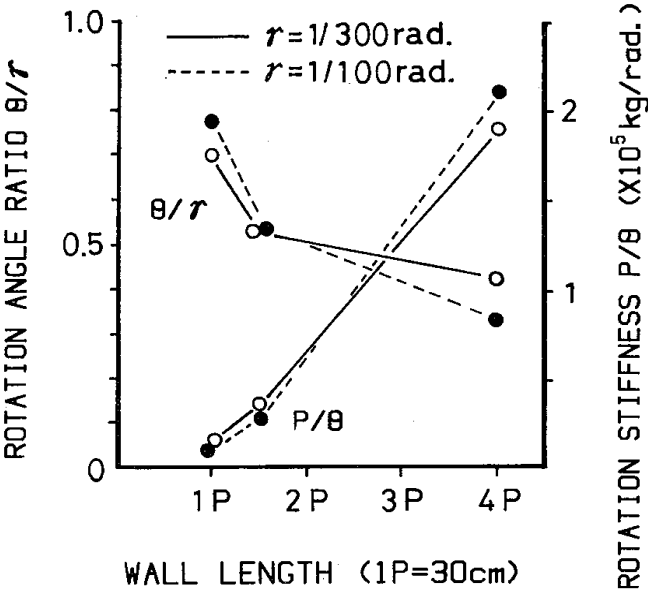

Fig. 12 Influence of wall length on the rotation angle ratio and rotation stiffness in noopening and vertical slit types

imately a half of that at the top. ( 2 ) In the window and door types, side walls are bent because of the existence of wall panels right above or/and below opening and this phenomenon is found much remarkably in the specimens having a larger opening ratio.

(3) Side walls having the same length (for example, VI-50, RI-50 and DI-50), rotate almost equally regardless of the shape of opening except for the specimen with window (WI-50).

\subsubsection{DEFORMATION IN GROUP II SPECIMENS}

The following tendencies can be found from Figs. 7, 9 and 11 ;

(1) In the specimens in which plywood sheets are sheathed all vertically (BV II , W II -25 and D II -25), plywood sheets displaced and rotated independently. (2) In the specimens in which wall parts right above and/or 
below opening were separately sheathed from side walls (W II -50 and D II -50), side walls were less bent than in the specimens sheathed with a single piece of plywood (WI-50 and DI-50) because of the large relative slip of plywood sheets at plywood joints. (3) Among the specimens with opening length ratio of $50 \%$, vertical slit type is the biggest in the rotation of side walls, and door type and window type follow in that order.

The above results indicate that, in the wall panel in which several plywood sheets are applied by nailing, each plywood sheet rotates and displaces remarkably and consequently it prevents plywood from tension failure.

\subsection{ROTATION OF NO-OPENING WALLS (GROUP I )}

Fig. 12 shows the influence of wall length on rotation angle ratio and rotation stiffness in the no-opening and vertical slit types. Here rotation angle ratio $\theta / \gamma$ is defined as the ratio of rotation angle $\theta$ to apparent shear strain $\gamma$ (See Fig. 5) and rotation stiffness $P / \theta$ represents the ratio of shear load to rotation. It can be found from Fig. 12 that rotation angle ratio decreases and rotation stiffness increases with the increase of wall length.

\subsection{DEFORMATION OF PLYWOOD IN GROUP II SPECIMENS}

\section{(A) DEFINITION}

Rotation and shear strain of each plywood sheet in Group II specimens were measured to investigate the force transmission in a wall penel.

Rotation and shear strain of a plywood sheet are defined as follows (See Fig. 13);

Rotation of plywood :

$$
\theta_{P}=\frac{\delta_{4}-\delta_{3}}{a}
$$

Shear strain of plywood :

$$
\gamma_{P}=\frac{\delta_{1}-\delta_{2}}{h}-\theta_{P}
$$

Shear strain ratio of plywood:

$$
R_{P}=\frac{\gamma_{P}}{\gamma_{P}+\theta_{P}}
$$

When the plywood sheet is applied vertically from bottom plate to top plate, the shear strain ratio of plywood represents the ratio of shear strain of plywood to apparent shear strain of a whole wall panel which includes not only the shear deformation of plywood and the rotation of plywood due to nail slip but also the rotation of the bottom of a wall panel.

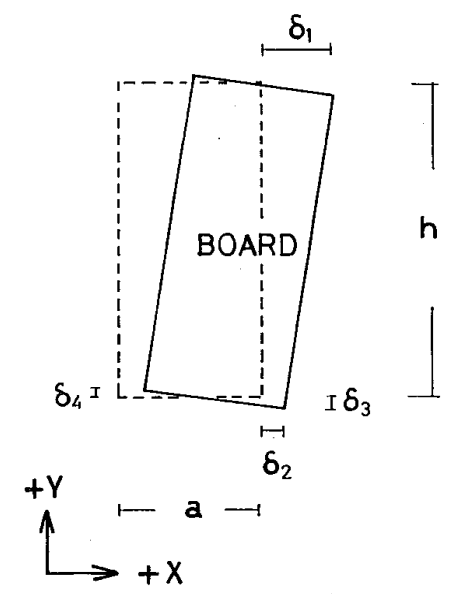

Fig. 13 Rotation and shear strain of plywood sheet

That is,

$$
\gamma_{P}+\theta_{P} \fallingdotseq \gamma
$$

Where, $\gamma=$ apparent shear strain of a wall panel.

Fig. 14 shows the relation between shear strain ratio of each plywood sheet and apparent shear strain of a wall panel.

\section{(B) DISCUSSION}

i ) Specimens in which plywood sheets are all applied vertically (BV II , W II -25 and D II -25)

As seen in Fig. 14, the shear strain ratio of plywood $A$ and $B$ arranged at outer sides of wall panel $B V I I$ is averagely 0.24 for the entire range of apparent shear strain of a wall panel. On the other hand, the average value of shear strain ratio for plywood C and D arranged at the inside of a wall penel is about 0.75 at apparent shear strain of $1 / 300 \mathrm{rad}$, and decreases with the increase of apparent shear strain and reaches down to about 0.4 at apparent shear strain of $1 / 60 \mathrm{rad}$. Quite similar trend is observed in W II -25 and D II -25.

The fact that the shear strain ratio of plywood arranged at the inside of a wall panel is larger than that arranged at outer sides of a wall panel means that the latter rotates in larger degree than the former, and consequently a large part of shear force applied to a wall panel is shared by the former.

ii ) Specimens in which plywood sheets are all horizontally applied ( $\mathrm{BH}$ II )

As seen in Fig. 14, the values of shear strain ratio for plywood sheets A, B, C and D in BH II are averagely $0.68,0.59,0.46$ and 0.46 respectively, and keep almost constant value regardless of apparent shear strain of a 


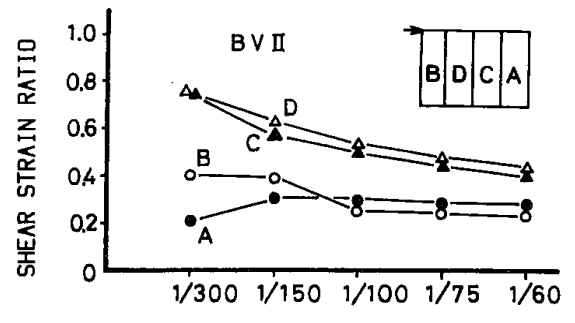

APPARENT SHEAR STRAIN (rad.)

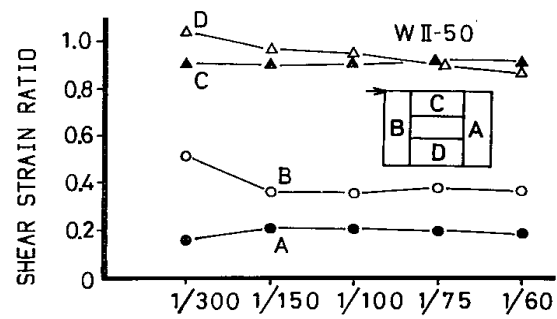

APPARENT SHEAR STRAIN (rad.)

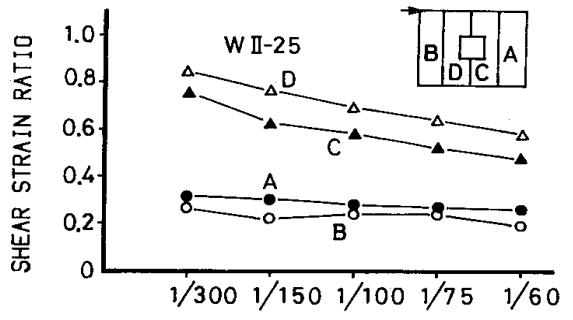

APPARENT SHEAR STRAIN (rad.)

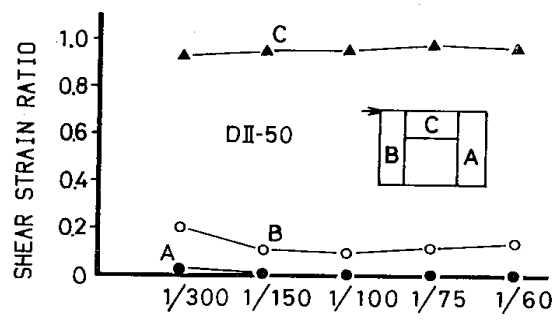

APPARENT SHEAR STRAIN (rad.)

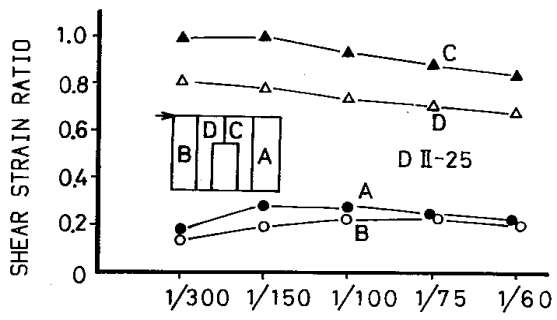

APPARENT SHEAR STRAIN (rad.)

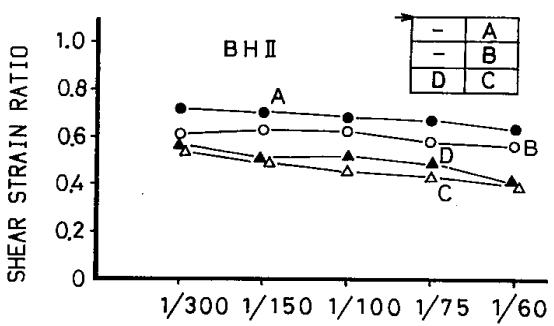

APPARENT SHEAR STRAIN (rad.)

Fig. 14 Relation between shear strain ratio of each plywood sheet and apparent shear strain of wall panel in Group II specimens

wall panel. It can be said from the above results that plywood sheets arranged at the top row of a wall panel is largest in shear strain ratio, and those arranged at the middle row and at the bottom row follow in that order.

iii) Specimens in which plywood sheets above and/or below opening are separately applied from others at the outer side (W II -50 and D II -50)

As seen in Fig. 14, the shear strain ratio of plywood sheets C and/or D keep almost constant value of 0.9 regardless of apparent shear strain of a wall panel. This indicates that plywood sheets above and below a window do not rotate. Plywood sheets $\mathrm{A}$ and $\mathrm{B}$ of $\mathrm{W}$ II -50 , which keep almost constant values of shear strain ranging 0.2 to 0.4 regardless of apparent shear strain of a wall panel, showed similar property to those of specimens BV II , W II -25 and D II -25. In D II -50, the shear strain of plywood sheets A and B are almost zero. This indicates that plywood sheets arranged at the outer side in door type specimen shows only rotation.

\section{5 INFLUENCE OF OPENING ON SHEAR STRENGTH}

Figs. 15 and 16 show the influence of opening length ratio on load at apparent shear strain of $1 / 100 \mathrm{rad} .\left(P_{100}\right)$ and ultimate load $\left(P_{\max }\right)$, respectively. These figures indicate that;

(1) $P_{100}$ and $P_{\max }$ can be expressed by a similar empirical curve as a function of opening length ratio, (2) $P_{100}$ and $P_{\max }$ in window type decrease almost linearly with the increase of opening length ratio, and (3) $P_{100}$ and $P_{\max }$ in door type take intermediate values between those in window and vertical slit types.

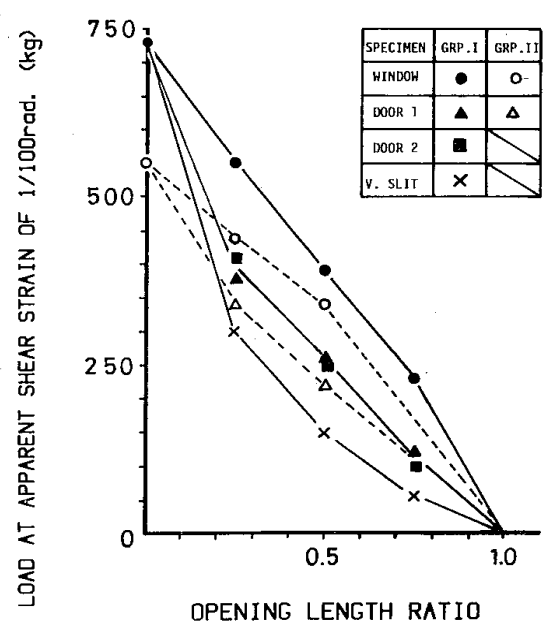

Fig. 15 Relation between opening length ratio and load at apparent shear strain of $1 / 100 \mathrm{rad}$.

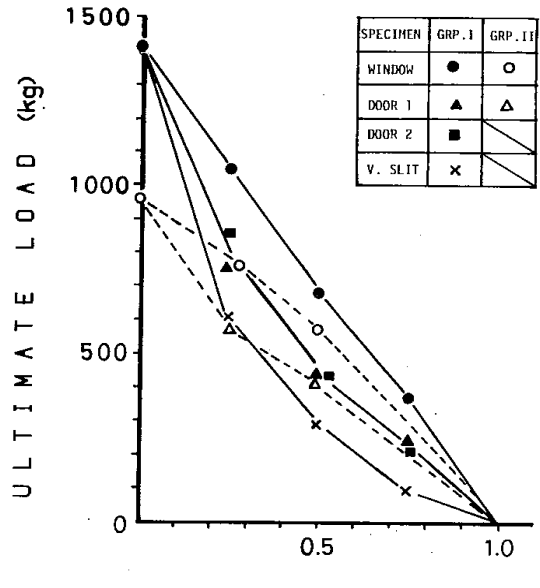

OPENING LENGTH RATIO

Fig. 16 Relation between opening length ratio and ultimate load

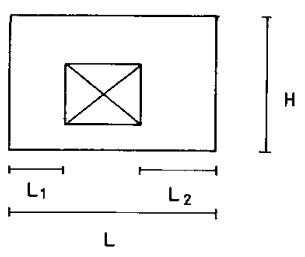

$\alpha=$ OPENING AREA RATIO $=\frac{\Lambda_{0}}{H L}$

$\beta=$ WALL LENGTH RATIO $=\frac{\Sigma L_{i}}{L}$

$r=$ OPENING COEFFICIENT

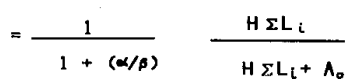

$A_{0}=$ SUM OF OPENING AREAS

Fig. 17 Definition of opening coefficient 


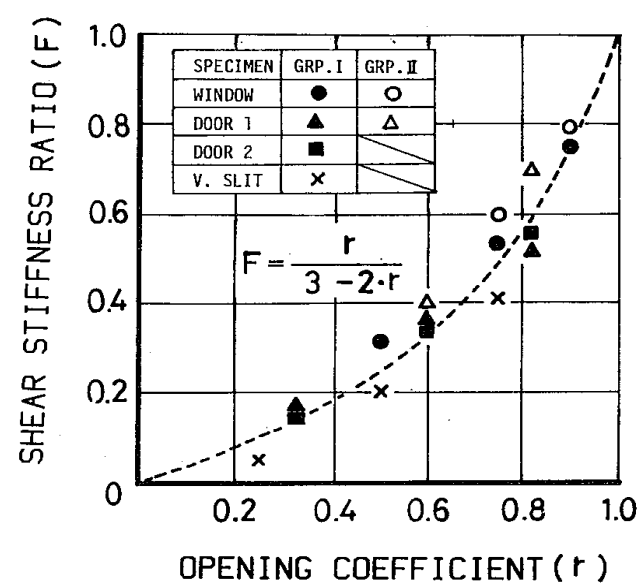

Fig. 18 Relation between the opening coefficient and shear stiffness ratio at apparent shear stain of $1 / 100 \mathrm{rad}$.

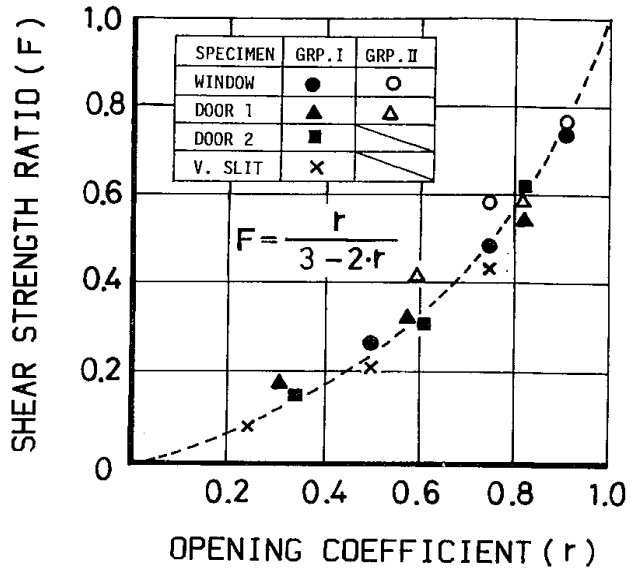

Fig. 19 Relation between the opening coefficient and shear strength ratio

Figs. 18 and 19 show shear stiffness ratio at apparent shear stain of 1/100 rad. and shear strength ratio for opening coefficient ${ }^{(4)}$, respectively. "Opening coefficient" (4) is defined in Fig. 17, and "Shear stiffness ratio" and "Shear strength ratio" are defined respectively as the "ratio of shear stiffness of wall panel with openings to that of no-opening wall panel" and the "ratio of shear strength of wall panel to that of no-opening wall panel".

From Figs. 18 and 19, it is observed that ; (1) Relation between shear stiffness ratio and opening coeffcient is quite similar to that between shear strength ratio and opening coefficient. (2) Both shear stiffness ratio and shear strength ratio increase in the same way with the increase of opening coefficient regardless of the shape of opening and the application method of plywood.

The above things suggest that Figs. 18 and 19 make it possible to predict the shear stiffness and strength of a wall with various types of opening from a racking test of no-opening wall. However, more experimental data on full-size wall would be necessary to apply this design procedure to the prediction of shear stiffness and strength of a wall.

\section{CONCLUSION}

Summarizing the discussions mentioned above, the followings can be concluded.

(1) In the wall panel with opening and sheathed with a piece of plywood, side wall is bent considerably due to the existence of wall parts above and below an opening, and consequently causes the failure of plywood around the corners of an opening.

(2) In the wall panel in which several plywood sheets are applied by nailing, the rotation and slip of each plywood sheet release the concentration of stress around the corners of an opening, and consequently prevent the plywood from tension failure.

(3) In the wall panel with a vertical slit, the greater part of deformation of a comparatively short side wall is due to the rotation, and shear stiffness of plywood did not contribute sufficiently to increase the resistance against horizontal force.

(4) In the wall panel in which plywood sheets are applied vertically, the larger part of shear force is shared by the plywood sheets arranged at the inside of a wall panel rather than those at the outer side. This is because the latter rotates more than the former.

( 5 ) In the no-opening wall panel with plywood sheets applied holizontally in three rows, the plywood sheets at the top row is largest in resistance against the shear force, and plywood sheets at the row and the bottom followed in that order.

(6) Plywood sheets above and/or below opening have little rotation, when applied separately from plywood sheets at the outer side. In this panel type, plywood sheets at the outer side rotate much more in the door type than in the window type.

(7) The relation between the opening coefficient and the shear stiffness ratio (Fig. 18) is quite similar to 
that between the opening coefficient and the shear strength ratio (Fig. 19).

( 8 ) The shear stiffness ratio and shear strength ratio increase in the same trend according to the increase of the opening coefficient regardless of the shape of opening and the method of application of plywood sheet.

(9) By using Figs. 18 and 19, the shear stiffness and strength of a wall panel with various types of opening can be estimated without making a racking test, as far as the shear stiffness and the strength of no-opening wall panel having the same size as that with opening are known.

\section{REFERENCES}

1) ARIMA, T. "Studies on the Wood-based Shear Walls being subjected to Cyclic Horizontal Loading to Constant Vertical Load ( 1 )", Summary of Technical Paper of Meeting of Kanto Chapter, Architectural Institute of Japan (1976)

2) ARIMA, T. “idem ( 2)", Summary of Technical paper of Annual Meeting 1976, Architectural Institute of Japan, 1671-1672 (1976)

3) KAMIYA, F., HIRASHIMA, Y., HATAYAMA, Y. and KANAYA, N. "Studies on Wood-Panel Construction ( I) Effect on racking resistances of bearing wall due to testing methods and wall length", BULLETIN OF THE FORESTRY AND FOREST PRODUCTS RESEARCH INSTITUTE No. 315. March 1981.

4) SUGIYAMA, H. "The Evaluation of Shear Strength of Plywood -sheathed Wall with Opening", Wood Industry, 36 ( 7 ), 3-8 (1981)

5) SUGIYAMA, H., YANAGIDA, Y. and YASUMURA, M. “The Influence of Opening on the Shearing Properties of the Bearing Wall constructed with North American Wood Framing Method", Summary of Technical Paper of Annual Meeting 1976, Architectural Institute of Japan, 1673-1674 (1976)

6) YASUMURA, M. "Influence of Opening on the Shear Properties of Plywood-sheathed Wall Panels", Doctoral Dissertation presented to Department of Forest Products, the University of Tokyo (1981)

7) YASUMURA, M, and SUGIYANA, H. "On the Deformation Behaviors of Individual Plywood-sheathings of Northwestern Type of Wooden Bearing Wall with Opening under Shearing Force”, Summary of Technical Paper of Annual Meeting 1979, Architectural Institute of Japan, 1789-1790 (1979)

\section{開口を持つ合板釘打ち張り耐力壁のせん断性状(梗概)}

$\begin{array}{llll}\text { 正会員 安 } & \text { 村 } & \text { 基* } \\ \text { 正会員 } & \text { 杉 } & \text { 山 } & \text { 英 } \\ \text { 男** }\end{array}$

\section{1. 緒 言}

わが国では木質構造の建物の水平力に対する設計に 当っては，一般に無開口の耐力壁が水平力の 3 分の 2 を 負担し, 残り 3 分の 1 を所謂非耐力部分 (垂れ壁, 腰壁, 直交壁等) が負担すると大ざっぱに仮定して設計を行っ てきた。この方法は，計算が簡単であるという利点を有 するが，䈌密には垂れ壁，腰壁等の多寡によりその水平 力負担の割合が変化するはずである。

そこで，この問題を解決するため，枠組壁工法の開口 をもつ合板張り壁をとりあげ，そのせん断耐力評価に必

* 建設省建築研究所第三研究部 研究員・農博

** 東京大学 教授 . 工博

(昭和 58 年 7 月 14 日原稿受理日, 昭和 58 年 12 月 16 日改訂原稿受 理日, 討論期限昭和 59 年 7 月末日)
要な資料を得る目的で, 開口の形状・法, 合板の張り 方が壁のせん断耐力に与える影響を実験的に調べてみ た。なお，試験体には実大の 3 分の 1 の縮尺の模型を用 いた。

\section{2. 試験体}

試験体は実大の合板釘打ち張りパネル（枠組壁工法） の縮尺 3 分の 1 の模型で, すべての部材寸法は㬰大の 3 分の 1 であった。すなわち，枠材およびまぐさ材しして， それぞれ $1.3 \times 3.0 \mathrm{~cm}$ (実大 $3.9 \times 9.0 \mathrm{~cm}$ に相当）扰よ び $2.6 \times 3.0 \mathrm{~cm}$. (合板の継目部分の枠用) のベイツガを 用い，シージング材としては夕イプIIの $3 \mathrm{~mm}$ 合板を使 用した。

試験体の構造はFig. 1 に示す通りで, $15 \mathrm{~cm}$ 間隔に配 した枠材の片面に $3 \mathrm{~mm}$ 合板を N19（直径 $1.5 \mathrm{~mm}$ ) で 
釘打ちした。釘間隔は，合板周辺部で $3.3 \mathrm{~cm}$ (実大 10 $\mathrm{cm}$ 間隔), 合板内部で $6.7 \mathrm{~cm}$ (実大 $20 \mathrm{~cm}$ 間隔) とし た。

試験体の種類はFig. 2 に示す通りで, 合板の張り方 により以下の 2 種類に大別した。

Group I（合板一枚張り式）：合板を張り継ぐことな く一枚張りしたパネル（縦スリット型を含む）。

Group II（合板張り継ぎ式）：数枚の合板を張り継い で釘打ちしたパネル。

なお, 試験体名の $\mathrm{W}$ は空型, D, R はドア型, B は 無開口型, $\mathrm{V}$ は縦スリット型を意味し, 試験体名最後の 数字 $(25,50,75)$ は, 開口部の巾之試験体の巾の百分 比（\%）を表す。

\section{3. 試験方法}

実験はFig. 3 に示す装置を用いて, 旧ASTM 試験法 に準じ，せん断試験を行った。すなわち，試験体下枠を 直径 $9 \mathrm{~mm}$ のボルト 4 本で $9 \mathrm{~cm}$ 角の木材土台に緊結し, 一方, 直径 $9 \mathrm{~mm}$ のボルト 4 本で試験体の上枠・頭継ぎ と $9 \mathrm{~cm}$ 角の加力用木材桁を緊結し，この桁に一方向ま たは両振れの水平荷重を加えた。

\section{4. 試験結果と考察}

\section{1 破壊性状}

合板一枚張り式の悹型およびドア型パネルでは， Fig. 4 (a) に示すように開口部の隅角部に合板の引張破 断および座屈が生じた。合板一枚張り式の無開口型, 縦 スリット型および合板張り継ぎ式パネルでは, 合板の引 張破断は見られず，枠材と合板を緊結している釘が大き くせん断変形し，合板からパンチアウトした（Fig.4 (b) 参照)。合板張り継ぎ式パネルで, 比較的大きな開 口を有するもの（W II-50，D II-50）では, 開口の隅角 部に合板の座屈が見られた。

\section{2 壁パネルの変形性状}

(A) 合板一枚張り式パネル

合板一枚張り式パネルの変形性状を示したFig. 6, 8 および 10 を眺めると， (1) 縦スリット型では, 左右の 袖壁がほぼ独立して，せん断変形および回転を行ってい る，(2) 空型およびドア型では，垂れ壁および腰壁の 存在により, 袖壁が大きく曲げられており,この傾向は 大きな開口長さを有するものほよ゙顕著である，（3）開 口長比が等しい試験体の袖壁の回転を比較すると,WI50 を除いて袖壁の回転は開口の形状によらずほぼ等し い。

(B) 合板張り継ぎ式試験体

合板張り継ぎ式パネルの変形性状を示したFig. 7, 9 および 11 を眺めると，（1）合板を縦張りにしたパネル (BV II ，W II-25，D II-25) では, 個々の合板がそれぞ れ独立して回転, 変形している, $(2)$ 垂れ壁, 腰壁部分 の合板を袖壁部分から分離して張り継いだパネル（W II
-50，D II-50）では，垂れ壁，腰壁の存在による袖壁の 曲げ変形は，合板を一枚張りにしたもの（W I-50, D I -50) と比べて小さい,（3）開口長比 $50 \%$ における袖 壁の合板の回転は, 縦スリット型が最も大きく, ドア型, 空型の順に回転が小さい。

\section{3 無開口型, 縦スリット型パネルの回転性状}

無開口型 (BI) および縦スリット型における壁長と 回転角比および回転剛性の関係はFig. 12 に示す通り で, 回転角比 (回転角 $\theta$ 亡見掛けのせん断変形 $\gamma$ 亡の比) は壁長の増加により下に凸の曲線を描き減少し, 回転剛 性 $P / \theta$ は, 見掛けのせん断変形に拘らず壁長の増加に 従って下に凸の曲線を描き増加している。

4.4 合板張り継ぎ式（Group II）における合板の変 形

(A) 定義

合板張り継ぎ式パネルにおける個々の合板の回転角お よびせん断変形角はFig.13 より, 以下の式で表される。 合板の回転角 $\theta_{P}=\frac{\delta_{4}-\delta_{3}}{a}$

合板のせん断変形角 $\gamma_{P}=\frac{\delta_{1}-\delta_{2}}{h}-\theta_{P}$

せん断変角比 $R=\frac{\gamma_{P}}{\gamma_{P}+\theta_{P}}$

せん断変角比 $R$ は，合板のせん断変形角之合板の見 掛けのせん断変形角の比を表し, 合板を縦張りした壁で は, 合板のせん断変形が壁の見掛けのせん断変形（合板 と枠材の間のスリップおよび枠組の回転を含む）に占め

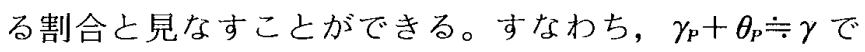
ある。ここに， $\gamma$ は壁の見掛けのせん断変形角を表す。

（II）合板をすべて縦張りした無開口壁パネル（BV II , W II-25, D II-25)

合板縦張り式無開口型（BVII）における外側に配置 した合板 A, B のせん断変角比 R は, Fig. 14 に示すよ うに,壁の変形に拘らずほぼ一定で,平均 0.29 であった。 一方, 内側に配置した合板 C, Dの R の值は, 壁の見 掛けのせん断変形角が $1 / 300 \mathrm{rad}$ 時で 0.75 であったが, 壁の変形の増加に従って減少し, 見掛けのせん断変形角 1/60 rad 時では約 0.4 に達した。この傾向は, W II-25, D II-25についても全く同様であり，壁パネルの両端に 配置された合板の回転が内側に配置されたものと比べて 相当大きいことを表している。

（C） 合板を横張りにした無開ロパネル（BH II） 合板横張り式無開口型（BH II）における合板 A, B, C, Dの Rの值は，それぞれ平均 $0.68 ， 0.59 ， 0.46$, 0.46 で,Fig. 14 に示すように壁の見掛けのせん断変形 に拘らずほぼ一定で，上方に配置した合板の $\mathrm{R}$ の值が 下方に配置したものより大きくなる傾向を示した。

（D）袖壁分離型開口部パネル（W II-50，D II-50） 袖壁部の合板から分離した垂れ壁，腰壁の合板 C,D 
の R の值はFig. 14 に示すように，壁の変形に拘らずほ ぼ 0.9 で，C，Dの合板がほとんよ゙回転していないこと を物語っている。W II-50における袖壁部の合板 $\mathrm{A}, \mathrm{B}$ の $\mathrm{R}$ の值は, 壁の変形にかかわらず 0.2 - 0.4 の範囲で, 合板縦張り式における合板 $\mathrm{A}, \mathrm{B}$ の R の值と同程度で あったが，DI-50における合板 A，Bの值はほぼ０（合 板が回転だけしたことを示す）であった。

\section{5 壁パネルのせん断耐力に与える開口の影響}

開口長比亡見掛けのせん断変形 $1 / 100 \mathrm{rad}$ 時の荷重あ るいは最大耐力との関係を示したFig. 15 および 16 を 眺めると，空型のせん断耐力は開口長比の増加に伴いほ ぼ直線的に減少した。また，ある開口長比に対するドア 型の耐力は，葖型と縦スリット型のほぼ中間にあり，垂 れ壁, 腰壁の壁全体のせん断耐力への寄与の度合がこれ から明瞭に看取される。

開口係数 (Fig. 17 参照 $)^{(4)}$ とせん断耐力比（開口パネ ルの耐力と同寸法の無開曰パネルとの耐力の比), ある いは終局耐力比の関係を示したFig. 18 および 19 を眺 めると, 開口係数亡せん断耐力比の関係は, 開口係数之 終局耐力比の関係亡酷似しており, 開口の形状 - 寸法に 拘らずほぼ同一の曲線で近似されることが分る。このこ とは，開口を有する壁パネルのせん断耐力を求める際に は，個々の開口パネルについてせん断試験を行わなくて も，これと同寸法の無開口パネルのせん断耐力および終 局耐力を知れば，前述の曲線を用い，開口壁パネルのせ ん断耐力を推定することができることを物語っている。

\section{$\S 5$ 結論}

以上の結果をさらに要約結論づけると次のことが言え よう。

1）縦スリット型パネルでは，左右の袖壁はほぼ独立 して，せん断変形および回転を行うが，空型および ドア型パネルでは, 垂れ壁, 腰壁の存在により袖壁 が大きく曲げられる。V I - 50，W II -50，D I -50の 袖壁部分の合板の回転はV I -50 が一番大きく, 次 いで W II -50，D II -50 の順である。
2）合板を縦張りにしたパネル $(\mathrm{BV}$ II $, \mathrm{W} I I-25, \mathrm{D}$ II -25）の場合，外側に配置した合板は，内側に配 置した合板と比べて壁の変形に占める合板の回転の 割合が大きい。合板を横張りにしたパネル (BH II ) では, 合程のせん断変形が壁の変形に上める割合は， 壁の変形に拘らずほぼ一定で，その割合は上方に配 置した合板が下方に配置したものと比べて僅かに大 きい。重れ壁・腰壁と袖壁を分離して張ったパネル

（W II -50，D II -50）では，袖壁の合板が壁の変形 において占める割合は大きく，壁の変形に拘らずほ ぼ一定であるが，垂れ壁，腰壁の合板はほとんど回 転しない。

3）空型のせん断耐力は開口長比の増加に伴いほぼ直 線的に減少し，ある開口長比に対するドア型の耐力 は，空型と縦スリット型のほぼ中間である。

4) 開口係数しせん断耐力比の関係は，開口係数亡終 局耐力比の関係に酷似し，開口の形状・寸法に拘ら ずほぼ同一の曲線で与えられている。従って開口壁 と同寸法の無開口壁のせん断耐力あるいは終局耐力 を知り得れば，この曲線を用いて開口壁パネルのせ ん断耐力あるいは終局耐力を推定することが可能で ある。

\section{訂正}

本会論文報告集第 329 号 (昭和 58 年 7 月号) 『Rigidity and strength of plywood-sheathed wall panels under reversed cyclic loading No.1：安村 基，杉山英男』 に下記のごとく誤りがありましたのでご訂正願います。 記

64 頁下から 4 行目：

正

were spaced $3.3 \mathrm{~cm}$ apart around the perimeters of $a$ plywood sheet and $6.7 \mathrm{~cm}$ along the intermediate supports 誤

were spaced $3.3 \mathrm{~cm}$ apart around intermediate supports 